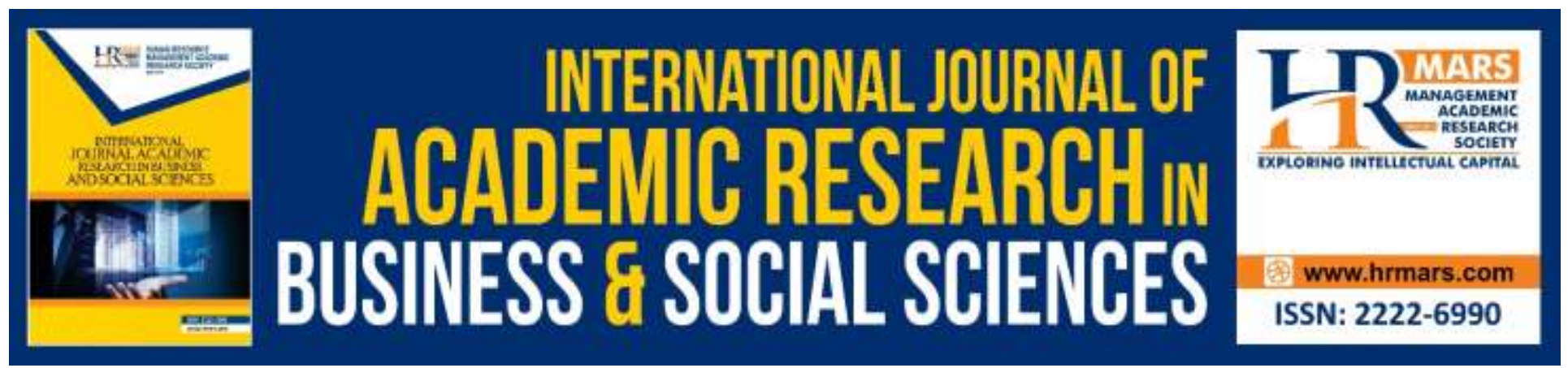

\title{
Determinant Factors Influencing EWOM Among Generation Y in Malaysia
}

\author{
N.H Marmaya, N. A. Razak, Melissa Wee, N. E. Alias, S.T Awang Tuah, N.A \\ Chek Talib, E A Marmaya
}

To Link this Article: http://dx.doi.org/10.6007/IJARBSS/v10-i4/7147

DOI:10.6007/IJARBSS/v10-i4/7147

Received: 08 February 2020, Revised: 10 March 2020, Accepted: 26 March 2020

Published Online: 20 April 2020

In-Text Citation: (Marmaya et al., 2020)

To Cite this Article: Marmaya, N. ., Razak, N. A., Wee, M., Alias, N. E., Tuah, S. . A., Talib, N. . C., \& Marmaya, E. A. (2020). Determinant Factors Influencing EWOM Among Generation Y in Malaysia. International Journal of Academic Research in Business and Social Sciences, 10(4), 459-467.

Copyright: (C) 2020 The Author(s)

Published by Human Resource Management Academic Research Society (www.hrmars.com)

This article is published under the Creative Commons Attribution (CC BY 4.0) license. Anyone may reproduce, distribute, translate and create derivative works of this article (for both commercial and non-commercial purposes), subject to full attribution to the original publication and authors. The full terms of this license may be seen at: http://creativecommons.org/licences/by/4.0/legalcode

Vol. 10, No. 4, 2020, Pg. 459 - 467

http://hrmars.com/index.php/pages/detail/IJARBSS

JOURNAL HOMEPAGE

Full Terms \& Conditions of access and use can be found at http://hrmars.com/index.php/pages/detail/publication-ethics 


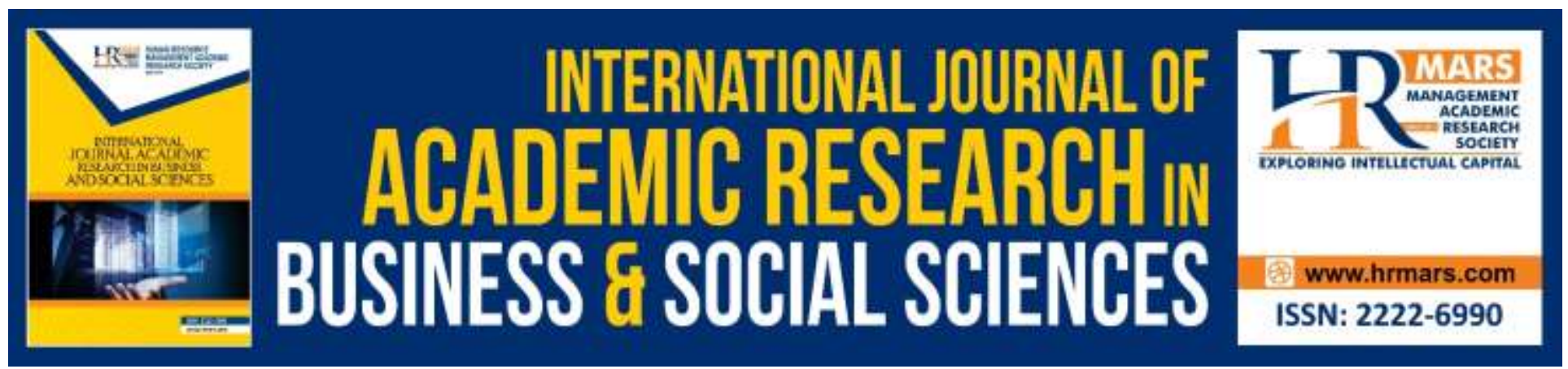

\title{
Determinant Factors Influencing EWOM Among Generation $\mathrm{Y}$ in Malaysia
}

\author{
N. H Marmaya, Senior Lecturer \\ Faculty of Business and Management, UniversitiTeknologi MARA Melaka, Malaysia \\ Centre For Islamic Philantrophy and Social Finance (CIPSF), UniversitiTeknologi MARA Melaka, \\ 75300 Melaka, Malaysia \\ Email: najihah@uitm.edu.my
}

\section{N. A. Razak, Melissa Wee, N. E. Alias, S.T Awang Tuah, N. A. Chek Talib}

Faculty of Business and Management, Universiti Teknologi MARA, Melaka, Malaysia

\author{
E. A. Marmaya \\ Ar Qs Consult, No.48-2, Kota Damansara, Petaling Jaya, Malaysia \\ Email: e_anyzah@yahoo.com
}

\begin{abstract}
The major purpose of this research is to discover the influences of Generation $Y$ to accept electronic word of mouth (eWOM). Apart vast research on the traditional word-of-mouth, only few have analysed electronic words of mouth from Malaysian generation $Y$ perspective. A quantitative method was adopted in this study and responses from 112 respondents among generation $Y$ in Malaysia that were analyzed using PLS-SEM. The result shows that there is significant relationship between Tech Savvy and trust toward eWOM behaviour among Generation Y. Practically, the result indicate that electronic word of mouth behaviour via social media and mobile technology can be part of marketing strategy to influence buyer to increase sales of product of a company. This empirical study attempts to enrich the understanding of electronic word of mouth behaviour via social media and mobile technology among Generation $Y$ within Malaysian context.
\end{abstract}

Keywords: Words of Mouth, Tech Savvy, Trust, Generation Y

\section{Introduction}

Internet plays an important part in our lives and has transformed our daily activities and communications with people. The Internet has allowed its users to see each other, hear each other 
INTERNATIONAL JOURNAL OF ACADEMIC RESEARCH IN BUSINESS AND SOCIAL SCIENCES Vol. 10, No. 4, April, 2020, E-ISSN: 2222-6990 @ 2020 HRMARS

and express their interests. This interaction is transforming the manner of people in the way they communicate, because we could reach others from all around the world with just one click. Internet advancement has grown and changed Word of Mouth (WoM) into something much more persuasive and quick-spreading- Electronic Word of Mouth (eWoM). Relate to the rapid progress of the Internet, there has been an extreme shift in WOM communication. Particularly, traditional WOM has developed into a new form of communication: electronic word-of-mouth communication (eWOM), in which online social networking has turned into a worldwide phenomenon and major part of the everyday activities of many purchasers around the globe. Along with traditional email interaction, watsapp, blogs, you tube and social networking sites, there has been a formation of online communities where people connect, communicate, follow current issues and convey their viewpoints more openly and actively than ever before across the world. Studies indicate that more than a third of online participants review products, frequently post opinions and participate in online content formation activities. It is a traditionally efficient method of obtaining convenient information for purchase decisions with word-of-mouth. Website quality and eWOM communications has received considerable attention in both online business and research communities (Aakash, Aggarwal, 2019). According to Malaysian Communications and Multimedia Commission (MCMC), impressive growth of internet user has given rise to 28.7 million with $\mathbf{8 7 . 4 \%}$ from the population. For social networking users, around $97.3 \%$ of netizens use Facebook, followed by Instagram (57\%) and Youtube (48.3\%). The most famous communication apps includes; Watsapp (91.8\%) followed by Facebook Messanger and WeChat (MCMC, 2019). Given the importance of internet among Malaysian, this research focuses on internet as emerging platforms for customer-to-customer communication, namely known as Word-of-Mouth (WOM). A majority of technology specialists and stakeholders believe that Generation $Y$ would guide society into a new world of personal experiential sharing and declaration using social media and mobile technology (Apresley, 2010; Bilgihanet al., 2014). Recently, Generation $Y$ has been the important role in many studies because of the dramatic diverse in terms of their attributes, behaviours, values and perceptions as compared to the previous circumstances (Hoyer and Macinnis, 2009). Thus, there are diverse terms extracted by divergent researchers on the Generation $Y$ cohorts. This generation also related to Millennial, Echo Boomers, Nexters and Net Generation (Tyler, 2008). The social media platforms such as Facebook, Twitter, LinkedIn, YouTube, WhatsApp, Instagram, and Google allow the young users to produce customized online pages, exchange information and interact with friends, as well as interchange content that they have created themselves (user-generated content) and or knowledge from other related brand. Even though electronic word of mouth has shown its success towards consumer viewpoint and behaviour (Marmaya, Balakrishnan and Shuaib,2018), little is known about the factors that influence word of mouth behaviour among generation $\mathrm{Y}$ in Malaysia. Hence, the objectives are:

1. To find out the influence of Tech Savvy Mobile Technology (TSMT) on Electronic Words of Mouth (eWOM) among Generation Y in Malaysia

2. To find out the influence of Trust on Electronic Words of Mouth (eWOM) among Generation $\mathrm{Y}$ in Malaysia 
INTERNATIONAL JOURNAL OF ACADEMIC RESEARCH IN BUSINESS AND SOCIAL SCIENCES

Vol. 10, No. 4, April, 2020, E-ISSN: 2222-6990 @ 2020 HRMARS

\section{Literature Review}

\section{Electronic Word of Mouth (eWOM)}

Abu bakar et al. (2016) defined eWOM as "any positive or negative statement made by present or previous customers about a product, service or company, which is made available to large audiences via the Internet". eWOM can take place through a wide range of online media such as emails, blogs, review sites, forums, virtual communities, chat rooms, instant messaging platforms. It is perceived well by academics and practitioners that electronic word-of-mouth (eWOM) marketing is a useful marketing strategy (Chu and Kim, 2011). eWOM marketing is attractive because it conquers consumer resistance, importantly costs low and convey quick - specifically via technology such as social media and mobile technologies. eWOM is described as the process that enable purchasers to express their thoughts through online and directs purchasers to favor and go against particular products. eWOM comprises open communications from purchasers regarding the attributes and features of products or brands. It is specifically significant feature in concurrent communication instruments, such as social media and mobile technologies.

\section{Tech Savvy of Mobile Technology (TSMT)}

People of all ages may grasp technology, but for Generation $Y$ members that live in a higher socioeconomic status developed with it and have occupied their entire lives interacted endlessly to a digital world. The social media, for example are Instagram, Facebook and Twitter, have played crucial part in the ways they work, study, travel, eat, make acquires and even entertain. Generation $Y$ buyers in those nations that produce sound information infrastructure visit Instagram, Facebook and Twitter to read opinions of services and products written by other purchasers. They are also developing as micro-bloggers who promote retail products on online platforms and receive insider information about brands via tweets (Bilgihan et al., 2013). Mobile technologies play an important part in improving Generation Y's knowledge and experience with social media in most developed nations (Cobanoglu et al., 2015). Muskat (2013) mentioned, Generation Y consumers find it easy to share their evaluations of service quality or an experience via social media. For these reasons, Generation $Y$ consumers are likely to disseminate positive or negative experience services following satisfactory service recovery because they can engage in eWOM with ease using technology. Hence, it is posited:

\section{H1: Tech Savvy Mobile Technology (TSMT) influence Electronic Words of Mouth (eWOM)}

\section{Trust}

According to McKnight, et al. (2002), trust is based on beliefs in the trustworthiness of an exchange party and the characteristics of competence, integrity, and kindness. Given the context of social media platforms, uncertainty is usually higher due to the high level of user-generated contents and the lack of face-to-face interactions (Featherman \& Hajli, 2015). The lack of face-to-face interactions could result in customers' suspicion of truthfulness in online exchanges and the paucity of knowledge about the e-vendors could further heighten the adverse influence of risk in online shopping (Kaiser \& Müller-Seitz, 2008). Kim \& Park (2013) investigate the antecedents of trust and its direct effects on purchase intentions and word-of-mouth intentions on social commerce platforms. Seven social commerce characteristics are identified as the key antecedents of trust: reputation, size, information quality, transaction safety, communication, economic feasibility, and word-of-mouth referrals. It is 
INTERNATIONAL JOURNAL OF ACADEMIC RESEARCH IN BUSINESS AND SOCIAL SCIENCES Vol. 10, No. 4, April, 2020, E-ISSN: 2222-6990 @ 2020 HRMARS

proposed that trust in a social media platform could increase customers' purchase intentions and also drove to willingness to spend on price premiums. Consumers are prone to trust their peers on Facebook rather than professional opinions on blogs or product review pages with opinions (Chu and $\mathrm{Kim}, 2011$ ). Instead of reading anonymous reviews of others, comments posted by Facebook peers may be recognized as more truthful and reliable. Thus, perceived trust should be evaluated as one of the factors that influence consumers' engagement behaviour in electronic word-of-mouth communication. It is posited that,

Hypothesis 3: Trust influence Electronic Words of Mouth (eWOM)

\section{Methodology}

\section{Measurement}

The measurements are developed based on extensive reviews of the literature. The survey is divided into two sections: the first section is designed to collect information on respondents' demographic profile, while the second section contains measurements on theoretical constructs for the present study. Second section consists of questions related to Tech Savvy by Sharma (2011), trust by Lu et al. (2010) and the electronic word of mouth (eWOM) behavior by Heung and Lam (2003). The survey is measured using the five-point Likert scale (i.e. $1=$ strongly disagree and $5=$ strongly agree).

\section{Sample}

The present study distributes a total of 130 questionnaires using convenience sampling and Generation $Y$ as the sample (20 to 37 years old). The collected responses are later screened and examined for incomplete responses and credibility. This initial procedure has resulted in the removal of 18 incomplete or unreliable responses (i.e. out of 130), thus leaving a total of 112 usable responses throughout the three regional locations. The data obtained are analysed using SmartPLS 2.0.

\section{Results}

Most of the respondents are female (61.7\%) followed by male (38.4\%) Bachelor Degree as the highest educational background followed by Diploma and SPM level and SPM level. Most of the respondents are between $20-25$ years old which contribute $60.0 \%$ of the total respondents whereas the second highest would be between $26-31$ years old with $22.5 \%$ and number of respondents at age $32-37$ years old contribute the remaining $17.5 \%$. The three groups are chosen to represent Generation $Y$ which falls between 20 years old to 37 years old. Data analysis is conducted using two-stage approach, namely, measurement and structural model. The details are as follows:

\section{Measurement Model}

The measurement model analysis is conducted for construct validity. Construct validity is composed of two components of convergent and discriminant validity. Convergent validity analysis comprises of average variance extracted (AVE) and composite reliability (CR). The reliability coefficient of factor structures is measured using the Cronbach's alpha. The coefficient alpha values for the five constructs range from 0.54 to 0.95 , demonstrating good internal consistency and strong reliability of each dimension (Hair et al., 2010). The constructs' validity is further examined using the convergent analysis. The results suggest strong convergent validity. Specifically, the computation of AVE ranges 
INTERNATIONAL JOURNAL OF ACADEMIC RESEARCH IN BUSINESS AND SOCIAL SCIENCES Vol. 10, No. 4, April, 2020, E-ISSN: 2222-6990 @ 2020 HRMARS

from 0.50 to 0.81 , higher than the Fornell and Larcker's (1981) recommended value of 0.50 . The reported CR exceeds the recommended value of 0.7 (Hair et al., 2012). Collectively, these results provide good support for soundness of scale structures (Table 1).

Table 1: Construct Reliability and Validity

\begin{tabular}{|l|r|r|r|}
\hline & $\begin{array}{c}\text { Cronbach's } \\
\text { Alpha }\end{array}$ & $\begin{array}{c}\text { Composite } \\
\text { Reliability }\end{array}$ & $\begin{array}{c}\text { Average Variance } \\
\text { Extracted (AVE) }\end{array}$ \\
\hline TECH SAVVY & 0.933 & 0.950 & 0.599 \\
\hline TRUST & 0.952 & 0.961 & 0.806 \\
\hline Ewom & 0.812 & 0.860 & 0.501 \\
\hline
\end{tabular}

The results of discriminant validity depict that the values in diagonal exceeding the threshold value of 0.70 demonstrate adequate discriminant validity.

\section{Structural analysis}

Table 2, shows the results of the hypotheses relationships. The analysis suggests a strong support on two of our posited hypotheses (i.e. $\mathrm{H} 1$ and $\mathrm{H} 2$ ). The analysis of $\mathrm{R}^{2}$ for eWOM is 0.51 . The result discovers that 52.1 per cent of the variation for eWOM could be explained by the dimension of Tech Savvy and trust. Following Hair et al.(2011), $\mathrm{R}^{2}$ values meet the requirement of 0.2 or 20 per cent in the consumers' research,suggesting that the current model is acceptable.

Table 2: Hypotheses testing

\begin{tabular}{|l|c|c|c|c|}
\hline Hypotheses & $\begin{array}{c}\text { Original } \\
\text { Sample }\end{array}$ & $\begin{array}{c}\text { T } \\
\text { Statistic } \\
\mathbf{S}\end{array}$ & $\begin{array}{c}\mathbf{P} \\
\text { Values }\end{array}$ & $\begin{array}{c}\text { Hypothesis } \\
\text { accepted/rejected }\end{array}$ \\
\hline $\begin{array}{l}\text { H1:Tech Savvy influence } \\
\text { eWOM }\end{array}$ & 0.252 & 3.469 & 0.000 & Accepted \\
\hline H2:Trust influence eWOM & 0.486 & 8.027 & 0.000 & Accepted \\
\hline
\end{tabular}

\section{Discussion}

This study discovers a significant relationship between Tech Savvy and trust towards eWOM. The results are supported by Kucukemiroglu and Kara (2015). These findings appear to suggest that generation $Y$ consumers who are Tech Savvy motivated to disseminate electronic word of mouth (eWOM) whether the experienced positive, negative or satisfactory recovery following a service failure, and there were no significant differences in the influence of social media on electronic word of mouth behavior (Zhang, Omran, \&Cobanoglu, 2017). This study also discovers a relationship between trust and eWOM. This result supported by Kucukemiroglu, \& Kara, (2015) who found that in virtual communities, trust plays a crucial part in influencing members' attitude, as an individual would behave proactively when they trust the situation and other people. Besides that, when two persons start to trust towards each other, they become more comfortable to convey their resources without afraid of being exploited by their peer. Thus, trust is one of the factors that influence Generation $Y$ to use electronic word of mouth behaviour. 
INTERNATIONAL JOURNAL OF ACADEMIC RESEARCH IN BUSINESS AND SOCIAL SCIENCES Vol. 10, No. 4, April, 2020, E-ISSN: 2222-6990 @ 2020 HRMARS

\section{Conclusion}

With the upshot popularity of usage online social media application was currently gaining rapid importance, current study elaborated more on the influence of Tech Savvy and Trust on eWOM among millennial in Malaysia. This is to enrich the understanding of electronic word of mouth behaviour via social media and mobile technology among Generation Y within Malaysian context. Current study could be quite operative in helping a customer to make decisions about purchasing. It should be interesting to introduce digital content and technologies that understand consumers behavior, to facilitate the decision making process through a user-friendly interface, by giving information related to products, promotions, new arrivals. The issue of how to effectively design and deploy social media platforms in this approach is most certainly an additional future research direction. It is clear that the social media platforms offer companies many opportunities to interact with consumers along with the entire decision-making process. Policy maker should increasingly put emphasis on Tech Savvy and Trust to influence electronic word-of-mouth efficiently. As social media application used by everyone around the world, electronic word of mouth tend to spread to everywhere and anyone who intent to review pre purchase of that desired goods and services. Improvise social media application in Malaysia should be enhanced. Some limitations should be acknowledged. First, the data collection for our present study is confined to respondents from Malaysia that indicates the generalisation issue. Future research should attempt to reach larger groups of respondents to validate the theoretical linkage tested in the present study. Secondly, this results in a relatively small size (112), compared with the population size. This also might affect the representative of the outcomes. There are several more suggestions to further extend the current model. First, the difference between different groups of respondents (female vs male, different age groups) could be examined. Also, the research model can be tested in different culture environment and investigates if people with different cultural background may assess eWOM in different ways.

\section{References}

Aakash, A., Aggarwal, A. G. (2019) Role of EWOM, product satisfaction and website quality on customer repurchase intention strategy and superior performance of micro and small businesses in volatile economies. IGI global, Hershey, pp 144-168.

Abu Bakar, A. M., Ilkan, M., Sahin, P. (2016) eWOM, eReferral and gender in the virtual community. Mark. Intell. Plan. 34(5), 692-710.

Apresley. (2010).Marketing to Generation Y. available

at.www.timeforge.com/site/blog/marketinggeneration-cash-elusive-demographic/ (accessed 25 October 2014).

Bilgihan, A., Peng, C., \& Kandampully, J. (2014). Generation Y's Dining Informantion Seeking and Sharing Behavior on Social Networking Sites: An Exploratory Study. International Journal of Contemporary Hospitality Management. Pp. 349-366.

Bilgihan, A., Okumus, F., Nusair, K., \& Bujisic, M. (2013). Online Experiences: Flow Theory, Measuring Online Customer Experience in e-Commerce and Managerial Implications for the Lodging Industry. Journal of Information Technology \& Tourism, 1-23.

Cobanoglu, C., Yang, W., Shatskikh, A., and Agarwal, A. (2015), "Are consumers ready for mobile payment? An examination of consumer acceptance of mobile payment technology in 
INTERNATIONAL JOURNAL OF ACADEMIC RESEARCH IN BUSINESS AND SOCIAL SCIENCES

Vol. 10, No. 4, April, 2020, E-ISSN: 2222-6990 @ 2020 HRMARS

restaurant industry", Hospitality Review, Vol. 31 No. 4, available at: http://digitalcommons.fiu.edu/ hospitalityreview/vol31/iss4/6 (accessed 6 June 2016).

Chu, S. C., \& Kim, Y. (2011). Determinants of Consumer Engagement in Electronic Word-of-Mouth (eWOM) in Social Networking Sites.International Journal of Advertising, 30(1) , 47-75.

Featherman, M. S., \& Hajli, N. (2015). Self-service technologies and e-services risks in social commerce era. Journal of Business Ethics, 1-19.

Fornell, C., and Larcker, D. F. (1981), "Evaluating Structural Equation Models with Unobservable Variables and Measurement Error, Journal of Marketing Research,Vol. 18 No. 1, pp. 39-50.

Hair, J. F., Black, W. C., Babin, B. J., and Anderson, R. E. (2010).Multivariate Data Analysis. 7th ed.,Prentice Hall, Englewood Cliffs.

Hair, J. F., Sarstedt, M., Ringle, C. M., and Mena, J. A. (2012).An Assessment of the Use of Partial Least Squares Structural Equation Modeling in Marketing Research", Journal of the Academy ofMarketing Science, Vol. 40 No. 3, pp. 414-433.

Heung, V. C., and Lam, T. (2003), "Customer complaint behaviour towards hotel restaurant services", International Journal of Contemporary Hospitality Management, Vol. 15 No. 5, pp. 283-289

Hoyer, W. D., \&Macinnis, D. J. (2009). Consumer Behavior (5th ed.). Mason, OH: South-Western Cengage Learning.

Kaiser, S., \& Müller-Seitz, G. (2008). Leveraging lead user knowledge in software development: The case of weblog technology. Industry and Innovation, 15(2), 199-221. doi:10.1080/13662710801954542

Kim, S., \& Park, H. (2013). Effects of various characteristics of social commerce (s-commerce) on consumers trust and trust performance. International Journal of Information Management, 33(2), 318-332. doi:10.1016/j.ijinfomgt.2012.11.006

Kucukemiroglu, S., \& Kara, A. (2015).Online Word-of-Mouth Communication on Social Networking Sites.pp.2-20.

Marmaya, N. H., Balakrishnan, B. K. P. D., \& Shuaib, A. S. M. (2018). Electronic Word-OfMouth (eWOM) Behavior in Malaysia: Successful Marketing Strategy. International Journal of Academic Research in Business and Social Sciences, 8(9), 1244-1255

Malaysian Communications and Multimedia Commission (MCMC), (2019) Internet User Survey 2018.

McKnight, D. H., Choudhury, V., \& Kacmar, C. (2002). Developing and validating trust measures for e-commerce: An integrative typology. Information Systems Research, 13(3), 334359. doi:10.1287/isre.13.3.334.81

Muskat, M., Muskat, B., Zehrer, A., and Johns, R. (2013), “Generation Y: evaluating services experiences through mobile ethnography", Tourism Review, Vol. 68 No. 3, pp. 55-71.

Lu , Y. Zhao, L. W. Bin. (2010), From virtual community members to C2C e-commerce buyers: Trust in virtual communities and its effect on consumers' purchase intention. Electronic Commerce Research and Applications, $9 \mathrm{pp}, 346-360$

Ravi S., \& Pandey, T. (2011). "The impact of electronic word of mouth in the distribution of digital goods." Webology, 8 (1) Article 84.

Kathryn, T. (2008).Generation Gaps.HR Magazines, Vol 53, 69-73. 
INTERNATIONAL JOURNAL OF ACADEMIC RESEARCH IN BUSINESS AND SOCIAL SCIENCES

Vol. 10, No. 4, April, 2020, E-ISSN: 2222-6990 @ 2020 HRMARS

Zhang, T., Omran, B. A., \& Cobanoglu, C. (2017). Generation Y's Positive and Negative eWOM: Use of Social Media and Mobile Technology, 732-761. 